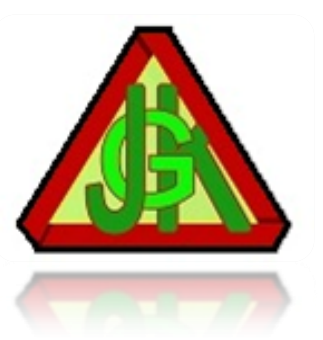

\title{
PENGARUH AKTIVITAS OLAHRAGA JALAN KAKI TERHADAP TINGKAT STRES PADA PEKERJA PHK AKIBAT CORONA VIRUS DISEASE 2019
}

\author{
${ }^{1}$ Ayu Dyah Kusumadewi Widiarsa, ${ }^{2}$ I Gede Widjanegara, ${ }^{3}$ I Nengah Sumirta \\ ${ }^{1,2,3}$ Politeknik Kesehatan Kemenkes Denpasar \\ Denpasar, Indonesia \\ e-mail: $\frac{\text { kusumadewi.widiarsa@gmail.com }{ }^{1}, \text { widjanegara@gmail.com }}{2}$,
}

\begin{abstract}
Abstrak
Stres merupakan respon diri dari berbagai masalah dan tuntutan yang dialami tiap individu dan apabila tidak dapat diatasi akan menyebabkan gangguan kejiwaan. Ada banyak cara yang dapat dilakukan untuk mengatasi stres, salah satunya aktivitas olahraga jalan kaki. Tujuan dari penelitian ini adalah untuk mengetahui pengaruh terapi aktivitas olahraga jalan kaki terhadap tingkat stres pada pekerja yang mengalami PHK akibat Covid-19 di Kecamatan Jembrana Tahun 2021. Desain penelitian ini menggunakan rancangan pra-eksperimental dengan pendekatan one-group pre-post test design. Cara pengambilan sampel adalah non probability sampling menggunakan metode purposive sampling. Jumlah sampel sebanyak 22 orang. Uji hipotesis menggunakan uji statistik Wilcoxon Sign Rank Test dengan nilai $p$ value $0,000(\alpha=0,05)$. Instrumen penelitian ini menggunakan Depression Anxiety Stress Scale 42 (DASS 42). Hasil penelitian menunjukkan ada pengaruh yang signifikan $(\mathrm{p}=0,000)$ terapi aktivitas olahraga jalan kaki terhadap tingkat stress pekerja PHK di Kecamatan Jembrana 2021 sehingga dapat disimpulkan bahwa terapi aktivitas olahraga jalan kaki menurunkan tingkat stress pekerja yang mengalami PHK. Dengan demikian, kepada para pekerja yang mengalami PHK agar meningkatkan kegiatan aktivitas fisik berjalan kaki agar merangsang produksi hormon endorphin.
\end{abstract}

Kata kunci : Terapi aktivitas olahraga jalan kaki, Stres, PHK

\begin{abstract}
Stress is a self-response to various problems and problems that each individual cannot overcome and will cause mental disorders. One way to overcome stress symptoms is by doing walking sports activity therapy. The purpose of this study was to determine the effect of walking exercise therapy on the stress level of workers who experienced layoffs due to Covid-19 in Jembrana District in 2021. The design of this study used a pre-experimental design with a one-group pre-post test design approach. The sampling method is non probability sampling using purposive sampling method. The number of samples is 22 people. Hypothesis testing used statistical Wilcoxon Sign Rank Test with a $p$ value $=0.000(\alpha=$ 0.05). The research instrument used the Depression Anxiety Stress Scale 42 (DASS 42). The results showed that there was a significant effect $(p=0.000)$ of walking sports activity therapy on the stress level of layoff workers in Jembrana
\end{abstract}


Ayu Dyah Kusumadewi Widiarsa, I Gede Widjanegara, I Nengah Sumirta.

Desember 2021. 14 (2): 113-125

District in 2021 and show that the walking sports activity therapy reduced the stress level of workers who had laid off. Thus, workers who have been laid off should increase their physical activity on foot to stimulate the production of endorphins.

Keywords:Walking sports activities, Stress, Layoffs

\section{PENDAHULUAN}

Severe Acute Respiratory Syndrome Coronavirus 2 (SARS-CoV-2) merupakan virus yang menyebabkan penyakit Corona Virus Disease 2019, atau yang saat ini dikenal dengan Covid-19. Virus ini pertama kali muncul di Wuhan, Provinsi Hubei, Cina pada tanggal 31 Desember $2019^{(1)}$. Menurut tinjauan literatur yang dilakukan oleh Susilo et al (2020), menyebutkan virus ini dapat ditularkan dari manusia ke manusia dan telah menyebar secara luas di China dan lebih dari 190 negara dan teritori lainnya. Hingga pada 11 Maret 2020 WHO mengumumkan Covid-19 sebagai pandemik ${ }^{(2)}$.

Pada tanggal 2 Maret 2020, kasus Covid-19 pertama kali dilaporkan di Indonesia dengan 56.385 kasus, hingga pada bulan Januari 2021 kasus positif corona mencapai 1,09 juta kasus ${ }^{(3)}$. Demi menekan persebaran virus corona, pemerintah Indonesia memberlakukan pembatasan kontak fisik (social distancing) dan melakukan pekerjaan dari rumah secara daring (work from home) ${ }^{(4)}$. Ketenagakerjaan merupakan satu dari sekian banyak sektor yang terdampak akibat kebijakan ini.

Menurut penelitian yang telah dilakukan oleh Randi (2020) menyebutkan pandemi Covid-19 menyebabkan menurunnya produktivitas pekerja, mengingat tidak semua jenis pekerjaan dapat dikerjakan di rumah. Hal ini menyebabkan banyak perusahaan melakukan pemutusan hubungan kerja terhadap pekerjanya demi menekan kerugian materi perusahaan. Menurut data dari Kemenaker RI (2020), jumlah pekerja yang terdampak Covid-19 pada bulan April 2020 adalah2.084.593. Di Bali jumlah pekerja yang dirumahkan dan di-PHK akibat akibat dampak dari Covid-19 sudah hampir menembus angka 50.000 orang pekerja. Data Dinas Tenaga Kerja ESDM Provinsi Bali hingga 13 April 2020, tercatat sebanyak 46.787 pekerja yang dirumahkan dan 824 pekerja di-PHK oleh 
606 perusahaan ${ }^{(7)}$. Berdasarkan hasil studi pendahuluan yang telah dilakukan di Kantor Pemerintahan Kabupaten Jembrana didapatkan data sebanyak 1284 orang mengalami PHK, khususnya di Kecamatan Jembrana sebanyak 243 orang.

Kebutuhan hidup yang terus berjalan namun tidak diimbangi dengan pemasukan menyebabkan masyarakat pekerja yang terkena PHK mengalami tekanan hingga berujung pada stres. Stres merupakan reaksi fisiologis dan psikologis yang terjadi jika seseorang merasakan ketidakseimbangan antara tuntutan yang dihadapi dengan kemampuan untuk mengatasi tuntutan tersebut. Akibat dari stress yang berkepanjangan ini dapat menimbulkan berbagai gejala yang dapat merugikan kesehatan fisik penderitanya, seperti gangguan pola tidur, perasaan malas, hingga hilangnya nafsu makan ${ }^{(8)}$. Aktivitas fisik merupakan salah satu terapi non farmakologis yang praktis dan sederhana serta dapat dilakukan oleh semua orang. manfaat yang didapat dari aktivitas fisik adalah pembakaran kalori dari setiap gerakan tubuh ${ }^{(9)}$. Salah satu aktivitas fisik yang paling mudah dilakukan adalah jalan kaki. Terapi ini memang terlihat ringan dan sederhana, namun jika dilakukan dengan terprogam dan terjadwal dengan baik akan mendapatkan hasil yang positif terhadap tingkat kesehatan ${ }^{(10)}$.

Studi Universitas Temple dalam Hidayah (2020) menyebutkan bahwa kegiatan berjalan kaki yag dilakukan selama 90 menit dengan frekuensi tiga kali seminggu akan memicu meningkatnya produksi hormon endorphin yang membuat tubuh lebih bugar dan mengurangi stres. Menurut penelitian yang telah dilakukan oleh Handayani dan Ratnasari (2019 )mengenai "Pengaruh Physical Exercise Terhadap Tingkat Stress Pada Ibu Bekerja di Sekolah Tinggi Kesehatan" menggunakan metode quasi experiment dengan one group pre-post-test design didapatkan bahwa ada pengaruh physical exercise terhadap tingkat stress ibu bekerja dengan nilai $\mathrm{p}$ value $=0,000$, yang berarti latihan fisik secara signifikan meningkatkan kekuatan dan daya tahan sehingga seseorang menjadi lebih bugar, kesehatan fisik dan mental terjaga.

Penelitian lain mengenai terapi aktivitas fisik juga didapatkan sebagai berikut, yakni menurut Sapti (2019) mengenai "Efektivitas Outbond Management Training Terhadap Stres Kerja Pada Pegawai Bank Swasta Di Surakarta" 
menggunakan metode penelitian eksperimen pretest post control group design, kemudian hasil penelitian ini dianalisis menggunakan Gain-Score dan diuji dengan independent sample test diperoleh nilai $\mathrm{t}=-9,790$ dengan taraf siginifikansi $(p)=0,000$ berarti terdapat perbedaan tingkat stress kerja karyawan bank sebelum dan sesudah Outbound Management Training (OMT). Berdasarkan latar belakang yang telah dipaparkan, secara umum penelitian ini bertujuan untuk membuktikan "Pengaruh Aktivitas Olahraga Jalan Kaki Terhadap Tingkat Stress pada Pekerja Yang Mengalami PHK Akibat Pandemi Covid-19 Di Kecamatan Jembrana Tahun 2021”.

\section{METODE}

Pada penelitian ini, digunakan jenis pra-eksperimental dengan cara memberikan tes pada saat sebelum dan setelah intervensi dalam suatu kelompok (one-group pretest-posttest-design). Suatu kelompok dilakukan observasi pada saat sebelum dan setelah dilakukan intervensi untuk mengungkapkan pengaruh atau hubungan yang ada ${ }^{(14)}$. Penelitian dilakukan di Kecamatan Jembrana pada bulan April sampai Mei 2021.

Pada penelitian ini teknik sampling yang digunakan adalah non-probability sampling yaitu purposive sampling, dengan cara memilih sampel berdasarkan kebutuhan atau yang dikehendaki peneliti dan dapat mewakili karakteristik populasi penelitian. Pemilihan sampel dilakukan secara langsung dan memenuhi kriteria inklusi yang telah ditetapkan ${ }^{(14)}$. Sampel yang digunakan pada penelitian ini adalah pekerja yang mengalami pemutusan hubungan kerja akibat pandemi Covid-19 di Kecamatan Jembrana dengan memperhatikan kriteria inklusi dan eksklusi yang ada, dan didapatkan sebanyak 22 orang yang telah dihitung dengan menggunakan rumus Pocock.

Instrumen pada penelitian ini menggunakan kuesioner DASS 42 yang telah dilakukan uji validitas dan uji reliabilitas sebelum digunakan. Kuisioner ini terdiri dari 21 pertanyaan yang dirancang sedemikian rupa untuk mengukur tingkat depresi, keecemasan, dan stress. Dalam DASS 42 terdapat 42 pertanyaan untuk mengukur tingkat stres dengan empat rentang skala, yang dimana skala 0 
merupakan pernyataan tidak pernah, skala 1 untuk kadang-kadang, skala 2 untuk sering, dan skala 4 untuk sangat sesuai atau dialami hampir setiap saat. Kategori skor dalam DASS 42 antara lain, 0-14 (normal); 15-18 (ringan); 19-25 (sedang); 26-33 (berat);>34 (sangat berat).

Data yang dikumpulkan pada penelitian ini adalah data primer dan data sekunder. Data primer adalah seluruh data yang berhasil dikumpulkan sendiri oleh peneliti baik melalui survey, pengamatan, hasil pengukuran, dan lain-lain ${ }^{(14)}$. Data primer pada penelitian ini meliputi karakteristik responden dan tingkat stres pada pekerja dengan PHK di Kecamatan Jembrana yang didapatkan melalui lembar kuisioner sebelum dan sesudah diberikan terapi aktivitas fisik olahraga jalan kaki.

Data sekunder merupakan data yang diperoleh melalui suatu lembaga atau orang lain dan berupa dokumen ${ }^{(14)}$.Data sekunder dalam penelitian ini adalah gambaran umum dan jumlah pekerja yang mengalami PHK di Kecamatan Jembrana pada tahun 2021. Kemudian data yang didapat dianalisa menggunakan Analisa bivariat dan univariat. Analisa bivariat dilakukan untuk mengetahui perbedaan tingkat stres pada pekerja yang mengalami PHK di Kecamatan Jembrana sebelum dan setelah diberikan terapi aktivitas fisik olahraga jalan kaki dengan menggunakan uji statistik dalam program komputer.

Sedangkan Analisa univariat digunakan untuk mendeskripsikan karakteristik dari masing-masing variabel yang akan diteliti dengan menggambarkan setiap variabel dengan tabel distribusi frekuensi. Analisis ini digunakan untuk menguji hipotesis penelitian dan menarik kesimpulan, dengan tujuan untuk meperoleh data, kemudian mendeskripsikan dan meringkasnya, hingga menganalisis pola didalamnya. Variabel yang dianalisis pada penelitian ini adalah hasil pengukuran tingkat stres pada pekerja yang mengalami PHK sebelum dan sesudah diberi terapi aktivitas olahraga jalan kaki.

\section{HASIL DAN PEMBAHASAN}

Karekteristik usia subjek penelitian dibagi menjadi tiga kategori berdasarkan teori perkembangan. Santrock (2012) mengemukakan teori 
Ayu Dyah Kusumadewi Widiarsa, I Gede Widjanegara, I Nengah Sumirta. Desember 2021. 14 (2): 113-125

perkembangan yaituusia dewasa awal (20-30) tahun, dewasa madya (31-59) tahun, dewasa akhir $\geq 60$ tahun. Dalam penelitian ini usia $\geq 60$ tidak ditemukan. Subjek penelitian berdasarkan usia selengkapnya disajikan dalam tabel 1.

Tabel 1. Distribusi Frekuensi Karakteristik Subjek Penelitian Berdasarkan Usia di Kecamatan Jembrana Tahun 2021

\begin{tabular}{lcc}
\hline \multicolumn{1}{c}{ Usia (Tahun) } & $\boldsymbol{f}$ & $\boldsymbol{\%}$ \\
\hline $20-30$ & 10 & 45,5 \\
\hline $31-59$ & 12 & 54,5 \\
\hline$\geq 60$ & 0 & 0 \\
\hline Total & 22 & 100 \\
\hline
\end{tabular}

Tabel 1 menunjukkan bahwa usia subjek penelitian yang terbanyak pada rentang usia 31-59 tahun yaitu sebanyak 12 orang (54,5\%).

Tabel 2. Distribusi Frekuensi Karakteristik Subjek Penelitian Berdasarkan Jenis Kelamin di Kecamatan Jembrana Tahun 2021

\begin{tabular}{lcc}
\hline \multicolumn{1}{c}{ Jenis Kelamin } & $\boldsymbol{f}$ & $\boldsymbol{\%}$ \\
\hline Perempuan & 8 & 36,4 \\
\hline Laki-laki & 14 & 63,6 \\
\hline Total & 22 & 100 \\
\hline
\end{tabular}

Tabel 2 menunjukkan bahwa jenis kelamin pada subjek penelitian yang lebih banyak adalah laki-laki sebanyak 14 orang $(63,6 \%)$.

Tingkat pendidikan dikategorikan berdasarkan Undang - Undang Sistem Pendidikan Nasional No 20 Tahun 2003 yang membagi jenjang pendidikan formal terdiri atas pendidikan dasar, pendidikan menengah dan pendidikan tinggi. Karakteristik subjek penelitian berdasarkan pendidikan selengkapnya disajikan dalam tabel 3.

Tabel 3. Distribusi Frekuensi Karakteristik Subjek Penelitian Berdasarkan Pendidikan di Kecamatan Jembrana Tahun 2021

\begin{tabular}{lcc}
\hline \multicolumn{1}{c}{ Pendidikan } & $f$ & $\%$ \\
\hline Dasar & 0 & 0 \\
\hline Menengah & 11 & 50 \\
\hline Tinggi & 11 & 50 \\
\hline Total & 22 & 100
\end{tabular}

Tabel 3 menunjukkan bahwa subjek penelitian memiliki tingkat pendidikan yang seimbang antara pendidika menengah dan tinggi, yakni masing-masing 
Ayu Dyah Kusumadewi Widiarsa, I Gede Widjanegara, I Nengah Sumirta. Desember 2021. 14 (2): 113-125

berjumlah 11 orang $(50 \%)$.

Karakteristik subjek penelitian berdasarkan pekerjaan sebelum mengalami PHK selengkapnya disajikan dalam tabel 4.

Tabel 4. Distribusi Frekuensi Karakteristik Subjek Penelitian Berdasarkan Pekerjaan di Kecamatan Jembrana Tahun 2021

\begin{tabular}{lcc}
\hline \multicolumn{1}{c}{ Pekerjaan } & $f$ & \% \\
\hline Karyawan Honorer & 8 & 36,4 \\
\hline Karyawan Swasta & 14 & 63,6 \\
\hline Total & 22 & 100 \\
\hline
\end{tabular}

Tabel 4 menunjukkan bahwa sebagian besar subjek penelitian sebelumnya bekerja sebagai karyawan swasta yaitu sebanyak 14 orang $(63,6 \%)$.

Karakteristik subjek penelitian berdasarkan status selengkapnya disajikan dalam tabel 5 .

Tabel 5. Distribusi Frekuensi Karakteristik Subjek Penelitian Berdasarkan Status di Kecamatan Jembrana Tahun 2021

\begin{tabular}{ccc}
\hline Status & $f$ & \% \\
\hline Belum Kawin & 7 & 31,8 \\
\hline Kawin & 15 & 68,2 \\
\hline Total & 22 & 100 \\
\hline
\end{tabular}

Tabel 5 menunjukkan bahwa sebagian besar subjek berstatus kawin yaitu sebanyak 15 orang $(68,2 \%)$.

Dalam penelitian tidak ditemukan stres sangat berat sehingga hanya diuraikan stres ringan, sedang, dan berat. Hasil penelitian disajikan dalam tabel 6 .

Tabel 6. Distribusi Frekuensi Subjek Penelitian Berdasarkan Tingkat Stres Sebelum Diberikan Perlakuan Terapi Aktivitas Olahraga Jalan Kaki di Kecamatan Jembrana Tahun 2021

\begin{tabular}{lcc}
\hline \multicolumn{1}{c}{ Tingkat Stres } & $\boldsymbol{f}$ & $\boldsymbol{\%}$ \\
\hline Ringan & 5 & 22,7 \\
\hline Sedang & 15 & 68,2 \\
\hline Berat & 2 & 9,1 \\
\hline Total & 22 & 100
\end{tabular}

Tabel 6 menunjukkan tingkat stres sebelum diberikan perlakuan terapi aktivitas olahraga jalan kaki pada subjek penelitian sebagian besar berada pada kategori stres sedang yaitu sebanyak 15 orang $(68,2 \%)$. 
Ayu Dyah Kusumadewi Widiarsa, I Gede Widjanegara, I Nengah Sumirta. Desember 2021. 14 (2): 113-125

Hasil pengamatan tingkat stres pada pekerja PHK sebelum dan sesudah diberikan terapi aktivitas olahraga jalan kaki, disajikan dalam tabel 7.

Tabel 7. Tingkat Stres Sebelum dan Sesudah Diberikan Terapi Aktivitas Olahraga Jalan Kaki di Kecamatan Jembrana Tahun 2021

\begin{tabular}{|c|c|c|}
\hline Kode Responden & Skor Pre-Test & Skor Post-Test \\
\hline 001 & 15 & 12 \\
\hline 002 & 16 & 10 \\
\hline 003 & 22 & 11 \\
\hline 004 & 21 & 16 \\
\hline 005 & 20 & 17 \\
\hline 006 & 24 & 18 \\
\hline 007 & 22 & 18 \\
\hline 008 & 23 & 21 \\
\hline 009 & 25 & 19 \\
\hline 010 & 15 & 7 \\
\hline 011 & 20 & 19 \\
\hline 012 & 21 & 17 \\
\hline 013 & 20 & 19 \\
\hline 014 & 20 & 17 \\
\hline 015 & 20 & 15 \\
\hline 016 & 29 & 20 \\
\hline 017 & 19 & 13 \\
\hline 018 & 20 & 13 \\
\hline 019 & 21 & 16 \\
\hline 020 & 16 & 9 \\
\hline 021 & 18 & 7 \\
\hline 022 & 27 & 19 \\
\hline
\end{tabular}

Tabel 7 menunjukkan tingkat stres terendah sebelum perlakuan adalah 15 dan tertinggi 29. Sedangkan tingkat stres terendah setelah perlakuan adalah 7 dan tertinggi 20. Tingkat stres pada pekerja PHK setelah diberikan terapi atktivitas olahraga jalan kaki mengalami penurunan. Stres berat tidak ditemukan, dan pada beberapa subjek penelitian didapatkan skor normal. Hasil penelitian disajikan dalam tabel 8. 
Ayu Dyah Kusumadewi Widiarsa, I Gede Widjanegara, I Nengah Sumirta.

Desember 2021. 14 (2): 113-125

Tabel 8. Distribusi Frekuensi Subjek Penelitian Berdasarkan Tingkat Stres Setelah Diberikan Perlakuan Terapi Aktivitas Olahraga Jalan Kaki di Kecamatan Jembrana Tahun 2021

\begin{tabular}{ccc}
\hline Tingkat Stres & $\boldsymbol{f}$ & $\boldsymbol{\%}$ \\
\hline Ringan & 10 & 45,4 \\
\hline Sedang & 6 & 27,3 \\
\hline Normal & 6 & 27,3 \\
\hline Total & 22 & 100
\end{tabular}

Tabel 8 menunjukkan tingkat stres setelah diberikan perlakuan terapi aktivitas olahraga jalan kaki pada subjek penelitian sebagian besar berada pada kategori stres ringan yaitu sebanyak 10 orang $(45,54 \%)$.

Uji normalitas data perlu dilakukan sebelum pengujian hipotesis dan untuk mengetahui teknik uji hipotesis yang digunakan. Sugiyono (2019) mengemukakan uji normalitas perlu dilakukan untuk mengetahui sebaran data apakah variabel berdistribusi normal atau tidak. Uji normalitas data ini menggunakan uji normalitas Shapiro-Wilk karena subjek penelitian kurang dari 50. Data dikatakan berdistribusi normal jika nilai signifikan >0,05. Hasil uji normalitas data tingkat stres sebelum dan sesudah diberikan perlakuan terapi aktivitas olahraga jalan kaki disajikan dalam tabel 9.

Tabel 9. Hasil Uji Normalitas Data Tingkat Stres Subjek Penelitian Sebelum dan Sesudah Diberikan Perlakuan Terapi Aktivitas Olahraga Jalan Kaki di Kecamatan Jembrana Tahun 2021

\begin{tabular}{ccc}
\hline Tingkat Stres & \multicolumn{2}{c}{ Shapiro Wilk } \\
\hline & N & P \\
\hline Pre Test & 22 & 0,045 \\
\hline Post Test & 22 & 0,038 \\
\hline
\end{tabular}

Tabel 9 menunjukkan bahwa hasil uji normalitas sebaran pada variabel stres sebelum diberikan terapi aktivitas olahraga jalan kaki didapat $\mathrm{p}=0,45$ hasil tersebut lebih kecil dari $\mathrm{p}=0,05$ berarti data tidak berdistribusi normal. Hasil uji normalitas pada variabel stres sesudah diberikan perlakuan terapi aktivitas olahraga jalan kaki didapat $\mathrm{p}=0,038$ hasil tersebut lebih kecil dari $\mathrm{p}=0,05$ berarti variabel stres sesudah diberikan perlakuan terapi aktivitas olahraga jalan kaki juga tidak berdistribusi normal.

Hasil uji hipotesis ditentukan dari tingkat signifikansi atau nilai $\mathrm{p}$ yang 
Ayu Dyah Kusumadewi Widiarsa, I Gede Widjanegara, I Nengah Sumirta.

dipilih oleh peneliti, jika memilih singnifikansi 0,05 maka hipotesis akan diterima apabila nilai $\mathrm{p} \leq 0,05$. Teknik uji hipotesis yang digunakan adalah uji statistik non parametrik yaitu uji Wilcoxon Sign Rank Test. Hasil analisis dengan uji Wilcoxon Sign Rank Test disajikan dalam tabel 10.

Tabel 10. Hasil Analisis Pengaruh Terapi Aktivitas Olahraga Jalan Kaki Terhadap Tingkat Stres Pada Subjek Penelitian di Kecamatan Jembrana Tahun 2021

\begin{tabular}{ccc}
\hline Variabel & $\mathrm{n}$ & Pvalue \\
Pengaruh terapi jalan kaki sebelum perlakuan & 22 & \\
Pengaruh terapi jalan kaki sesudah perlakuan & 22 & 0,000 \\
\hline
\end{tabular}

Tabel 10 menunjukkan hasil uji hipotesis menggunakan uji Wilcoxon Sign Rank Test dengan jumlah jumlah subjek penelitian sebanyak 22 orang, diperoleh nilai $\mathrm{p}=0,000$ lebih kecil dari $\alpha=0,05$ berarti hipotesis diterima. Artinya terdapat pengaruh yang signifikan terapi aktivitas olahraga jalan kaki terhadap tingkat stres pada pekerja PHK di Kecamatan Jembrana tahun 2021, maka dapat disimpulkan bahwa terapi aktivitas olahraga jalan kaki dapat menurunkan tingkat stres pada pekerja yang mengalami PHK akibat Covid-19.

Hal ini dapat dilihat pada hasil pre test dan post test, yang dimana sebelum diberikan perlakuan semua responden mengalami stres, baik dalam kategori stres ringan, sedang, mau pun berat. Namun setelah diberikan perlakuan, tidak ada responden yang termasuk dalam kategori stres berat, beberapa responden berada pada kategori normal, dan kategori stres paling tinggi adalah stres sedang.

Peneliti belum menemukan penelitian lain yang sama persis dengan subjek pekerja PHK namun peneliti menemukan penelitian yang sejenis, yang dilakukan oleh Pratiwi (2019) dengan judul "Hubungan Aktivitas Fisik dengan Tingkat Stres Kerja pada Petugas Penjaga Lembaga Pemasyarakatan Kota Palembang Tahun 2020" yang menggunakan seluruh petugas penjaga lembaga pemasyarakatan Kota Palembang sebanyak 109 orang sebagai sampel dan didapatkan hasil bahwa terdapat hubungan yang signifikan antara aktivitas fisik ( $\mathrm{p}$-value $=0,000$ ) dengan tingkat stres kerja. Sehingga pekerja sangat dianjurkan untuk rutin melakukan 
aktivitas fisik lebih kurang 30 menit per hari.

Hal ini sesuai dengan pendapat Abd El-Kader SM (2016) mengenai aktivitas fisik, dengan melakukan aktivitas fisik secara konsisten memiliki dampak positif bagi tubuh, antara lain dapat mengurangi stres, depresi, dan perasaan cemas. Latihan fisik yang sesuai dijalani untuk menurunkan beberapa gangguan psikologis seperti depresi, stres, dan kecemasan adalah latihan aerobik. Latihan aerobik dengan cara berjalan pada treadmill sangat efektif dalam meningkatkan kualitas hidup dan menjaga kesehatan psikologis. Seperti yang telah disebutkan sebelumnya, latihan fisik memicu produksi hormon endorphin, sedangkan bila jarang berolahraga akan terjadi peningkatan hormon kortisol yang memicu stres.

Berdasarkan penelitian yang telah dilakukan didapatkan hasil bahwa pemberian terapi aktivitas olahraga berupa jalan kaki mampu menurunkan tingkat stres pada subjek penelitian secara signifikan hingga pada kategori tidak mengalami stres. Selain itu, setelah melakukan olahraga jalan kaki, subjek penelitian dapat beristirahat lebih baik dari sebelumnya dan merasa lebih segar. Peneliti berpendapat pemberian terapi ini sangat berguna dalam menjaga kesehatan psikologis maupun fisik dan sangat dianjurkan untuk dilakukan setiap hari untuk hasil yang lebih maksimal.

\section{SIMPULAN}

Tingkat stres pada pekerja PHK akibat Covid-19 sebelum diberikan terapi aktivitas olahraga jalan kaki menunjukkan sebagian besar pekerja PHK mengalami stres sedang sejumlah 15 orang $(68,2 \%)$. Tingkat stres pada pekerja PHK akibat Covid-19 setelah diberikan terapi aktivitas olahraga jalan kaki menunjukkan sebagian besar pekerja PHK yang mengalami stres ringan sejumlah 10 orang $(45,4 \%)$. Ada pengaruh yang signifikan $(\mathrm{p}=0,000)$ terapi aktivitas olahraga jalan kaki terhadap tingkat stres pada pekerja PHK akibat Covid-19 di Kecamatan Jembrana Tahun 2021. 
Ayu Dyah Kusumadewi Widiarsa, I Gede Widjanegara, I Nengah Sumirta.

Desember 2021. 14 (2): 113-125

\section{UCAPAN TERIMAKASIH}

Terimakasih kepada institusi Poltekkes Denpasar, Pemerintah Kabupaten Jembrana, serta semua pihak yang terlibat dalam penelitian ini yang tidak bisa disebutkan satu per satu.

\section{ETIKA PENELITIAN}

Etika Penelitian ini diperoleh dari Politeknik Kesehatan Kemenkes Denpasar.

\section{DAFTAR RUJUKAN}

1. Kemenkes RI. Peta Sebaran Transmisi Lokal Dan Wilayah Terkonfirmasi. 2020.

2. WHO. weekly epidemiological update. 2021.

3. Satgas Covid-19. PEDOMAN PENCEGAHAN DAN PENGENDALIAN CORONAVIRUS DISESASE (COVID-19). 2020;1-214.

4. Keputusan Menteri Kesehatan Republik Indonesia Nomor Hk.01.07/menkes/413/2020 Tentang Pedoman Pencegahan dan Pengendalian. 2020;

5. Randi Y. Pandemi Corona Sebagai Alasan Pemutusan Hubungan Kerja Pekerja Oleh Perusahaan Dikaitkan Dengan Undang-Undang Ketenagakerjaan. 2020;2:119-36.

6. Kemenaker RI. Menaker: Badai Pasti Berlalu, Panggil Kembali Pekerja yang ter-PHK Nanti di Panggil Kembali. 2020.

7. Balipost. Covid-19 Sebabkan Puluhan Ribu Naker Di Bali Dirumahkan, Ratusan Orang Di-PHK. 2020.

8. Buanasari A. Gambaran tingkat stres pada lansia. 2019;7.

9. Depkes RI. Pembinaan Kesehatan Olahraga di Indonesia. Pusat Data dan Informasi Kementrian Kesehatan RI, editor. Info Datin; 2015.

10. Subakti S. PENGARUH LATIHAN JALAN KAKI 30 MENIT TERHADAP PENURUNAN TEKANAN DARAH PADA PASIEN PENDERITA HIPERTENDI Di RUMAH SAKIT UMUM KABANJAHE. 2014;

11. Hidayah N, Keperawatan P, Politeknik L, Kemenkes K. Efektifitas Olahraga Jalan Kaki terhadap Penurunan Depresi pada Lan - sia di Panti Werdha. 2020;978-9.

12. Handayani PA, Ratnasari. Pengaruh Physical Exercise terhadap Tingkat Stress pada Ibu Bekerja di Sekolah Tinggi Kesehatan. J Holist Nurs Heal Sci. 2019;2(2):48-55.

13. Sapti M. EFEKTIVITAS OUTBOND MANAGEMENT TRAINING TERHADAP STRES KERJA PADA PEGAWAI BANK SWASTA DI SURAKARTA. Kemamp Koneksi Mat (Tinjauan Terhadap Pendekatan 
Ayu Dyah Kusumadewi Widiarsa, I Gede Widjanegara, I Nengah Sumirta. Desember 2021. 14 (2): 113-125

Pembelajaran Savi). 2019;53(9):1689-99.

14. Nursalam. Metodologi Penelitian Ilmu Keperawatan: Pendekatan Praktis. Jakarta: Salemba Medika; 2017.

15. Santrock JW. Life-Span Development Edisi 13 Jilid 1 \& 2. Erlangga; 2012.

16. Sugiyono. Metode Penelitian Kuantitatif, Kualitatif, dan R\&D. 2nd ed. Bandung: Alfabeta; 2019.

17. Fatimah, Pratiwi A. Patologi Kehamilan : Memahami Berbagai Penyakit dan Komplikasi Kehamilan. Yogyakarta: Pustaka Baru Press; 2019.

18. Abd El-Kader SM A-JO. Aerobic exercise improves quality of life, psychological well-being and systemic inflammation in subjects with Alzheimer's disease. Afr Health Sci. 2016. p. Vol 16 Issue 4, 1045-1055. 